\title{
Landslide vulnerability mapping (LVM) using weighted linear combination (WLC) model through remote sensing and GIS techniques
}

\author{
Elizabeth Aipe Michael $^{1} \cdot$ Sailesh Samanta ${ }^{2}$
}

Received: 16 May 2016/Accepted: 21 May 2016/Published online: 8 June 2016

(C) Springer International Publishing Switzerland 2016

\begin{abstract}
Weighted linear combination (WLC) method was used to assess landslides vulnerability of the Simbu Province, Papua New Guinea within the GIS environment of ArcGIS. This multi-criteria evaluation method allows flexibility and tradeoffs amongst all parameters used. Ranks and weights are assigned depending on their influence on the occurrence of landslides. Parameters selected for the study include slope angle, elevation, rainfall, vegetation cover, land use/land cover, landform, proximity to roads, proximity to rivers and proximity to lineaments. Restricted in some sense in terms of data, WLC was appropriate in using existing metadata of the country; Papua New Guinea Resource Information System and Forest Information Management System. The landslide susceptibility map provides valuable information of the risk at hand in the province and district levels to better manage and plan mitigation measures. The slope factor was assigned a weighted of 4 as having greater influence on landslides in the region followed by rainfall weighted of 2 and the other having uniform influence of 1 . The study area shows the distribution of the five vulnerability/susceptibility classes ranking from very low (1) to very high (5). Areas with very high landslide vulnerability zones are
\end{abstract}

Sailesh Samanta

rsgis.sailesh@gmail.com

Elizabeth Aipe Michael

eaipemichael@gmail.com

1 Mineral Resource Authority of Papua New Guinea, Mining Haus, Poreporena Freeway, P.O.Box 1906,

Port Moresby, NCD, Papua New Guinea

2 GIS Section, Department of Surveying and Land Studies, The PNG University of Technology, Private Mail Bag, Lae, Morobe, Papua New Guinea found in the northern and western parts of Simbu Province. Comparatively, southern parts have very low vulnerability areas. From the calculations done, $6.21 \%$ of area is at very low risk, $20.24 \%$ at low risk, $32.27 \%$ of moderate risk, $26.88 \%$ of high risk and $14.41 \%$ of very high risk area coverage.

Keywords GIS · Landslide · Vulnerability · Weighted linear combination $\cdot$ Mapping

\section{Introduction}

A single landslide event can cause enormous detrimental effects on the social, economic and environmental aspects of any country and its population especially for developing countries where early warning systems and mitigation measures are minimal. Countries along the equatorial and temporal regions are more vulnerable. The frequency of these occurrences has increased significantly over the recent years due to changing weather patterns, geological degradation, exponential human population growth, and unplanned infrastructure developments on high altitudes (Samy and Mohamed 2015; Kanungo et al. 2009). In the recent past individual events along the Simbu Section (likeGera landslide in 2008, Wainngar landslide in 2013 and Kenagi landslide in 2014) of the Highlands Highway have significantly cost the Government of Papua New Guinea (GoPNG) millions of Kina in rehabilitation and maintenance and loss of revenue for the booming mining and petroleum companies and businesses. Landslide is described as any downward movement of material, rock mass or debris under the influence of gravity in favourable slope conditions (Greenbaum et al. 1995; Nayak 2010). These movements can be either influenced by internal or external 
factors or interactively by both to initiate the movement, transport and deposition of slip material. The external factors include but not limiting to are earthquakes, rainfall, deforestation or human induced vibration weakening the internal cohesion of particles within the subsurface soil structures. Numerous investigations of individual landslide events have been recorded in the country but extensive quantitative regional or provincial scale susceptibility maps are non-existent for well informed decision making in infrastructure development and awareness programs in Papua New Guinea (PNG). Most of these investigated landslides have occurred within major infrastructure development or highly populated areas or have been disastrous. Due to rugged terrain and remoteness, records are not existent of landslides in $\sim 80 \%$ of the country.

This trend is likely to change with the application of remote sensing and GIS techniques using freely available satellite images and collateral metadata information. A GIS platform enables the manipulation of datasets that forms an initial assessment of the region and narrows field investigation to specific areas of interest saving cost and man hour. Remote sensing and GIS application are cross-sectoral approaches in all sectors of planning and managements. Remote sensing allows for regional and extensive data collection at any given time saving cost and time with comparative analysis over time (Samanta et al. 2011, 2012). Greenbaum et al. (1995) assessed the application of remote sensing and GIS as a rapid landslide mapping tool for Papua New Guinea, using the Kaiapit Landslide (in 1998) as a case study. Samanta and Bhunia (2013) applied remote sensing and GIS weighted sum application to generate a regional scale landslide susceptibility map for Markham watershed, Papua New Guinea. Depending on the scale and data availability, different methods are applied in Landslide Susceptibility Mapping. Techniques available and widely used are landslide inventories and qualitative approaches (Barredo et al. 2000). Landslide inventories are rudimentary analysis and recording of landslides that form the basis of "past is the key to the future". Old landslide areas are prone to reactivate due to pre-existing weak formation or subsurface material. Qualitative approaches depend on expert knowledge of causative parameters that can induce or trigger a landslide. Largely depended on expert knowledge there is no certain criteria used to select neither parameters nor the number of parameters used. Multiple parameters are combined in a GIS overlay environment to derive the resultant output. According to Nichol et al. (2006), the scale of the study can influence selection of parameters and level of detail required for the study.

For the purpose of this study, qualitative analysis approach is taken. The weighted linear combination (WLC) method, data driven analytical method involving multiple parameters is used to establish the relational importance and degree of influence of the selected parameters to enable a landslide event in a GIS environment (Mahini and Gholamalifard 2006; Ladas et al. 2007). According to Ladas et al. (2007) there is no standard number of parameters that can be selected which gives a degree of difficulty for WLC method. Though according to Malczewski (2000), that weights assigned do not concretely show the degree of influence and is highly based on assumptions, it can be argued, internal and external causative parameters are similar to some extend in the world for any landslide event with minimal differences. To some degree, trade-offs are made between all the parameters identified to achieve maximum possible conducive landside environment with flexibility (Mahini and Gholamalifard 2006; Shahabi and Hashim 2015). There is no single approved methodology for landslide susceptibility mapping but analysis applied depends on the quality and availability of datasets and scale of study (Greenbaum et al. 1995). Papua New Guinea lies within a tectonically active region and forms part of the Pacific Ring of Fire. The region is virtually rugged with high rainfall and seismic activities coupled with unplanned infrastructure developments makes it ideal for landslides occurrences. Though there are records of individual studies or investigations of landslides in the country based on geomorphological studies and site investigations, there is no record of a quantitative approach to create hazard susceptibility maps for the country. Ten parameters were considered appropriate for the location and scale of the study area; slope angle, elevation, rainfall, proximity to lineaments, landuse/landcover, geological unit, proximity to road, vegetation cover, proximity to drainage and landform. The study aims to incorporate Landsat remote sensing data and GIS overlaying capabilities to produce landslide susceptibility maps for the Simbu Province.

\section{Study area and its environmental condition}

The Simbu Province is prone to landslides and associated instability due to its rugged mountainous terrain at altitudes ranging from 1200 to $4500 \mathrm{~m}$ covering approximately 6157 square kilometres. It is located between longitudinal extension of $144.42^{\circ} \mathrm{E}-145.35^{\circ} \mathrm{E}$ and latitude of $6.87^{\circ} \mathrm{S}-$ $5.773410^{\circ} \mathrm{S}$. The lowest and highest ranges are associated with the Wahgi Valley trending northwest southeast on the western boundary and Mt Wilhelm towering at $4529 \mathrm{~m}$ north of Kundiawa Town respectively. The province is strategically divided into sevendistricts for equal distribution of services; Chuave, Sinasina, Kundiawa, Gembogl, Kerowagi, Gumine, and Karimui. Except for the Karimui District, others are connected by road to Kundiawa, 
Provincial Headquarters (Fig. 1). According to Bain and Mackenzie (1975), the seasonal variation in distinctly defined as wet and dry dominated by the northwest trade winds. The months between October to April, receive maximum rainfall with approximately $2000-2600 \mathrm{~mm}$ annually increasing towards the southeast. Slight maximum variation can be experienced in the southeast from May to August due to south-westerly winds. High mountains and windward areas receive higher rainfall (Bain and
Mackenzie 1975). Both surface runoff and subsurface infiltration increases during this period that significantly reduces the shear stress of the subsurface material. Temperatures in the Highlands Region range from 17 to $25^{\circ} \mathrm{C}$ with a daily variation of $2{ }^{\circ} \mathrm{C}$ but can be lower at altitudes higher than $4000 \mathrm{~m}$ above mean sea level. Mt. Wilhelm, the highest mountain in PNG and study area at $4509 \mathrm{~m}$ experiences occasional frost and snow falls (Bain and Mackenzie 1975). The region is largely covered by dense
Fig. 1 Location map of Simbu Province, Papua New Guinea
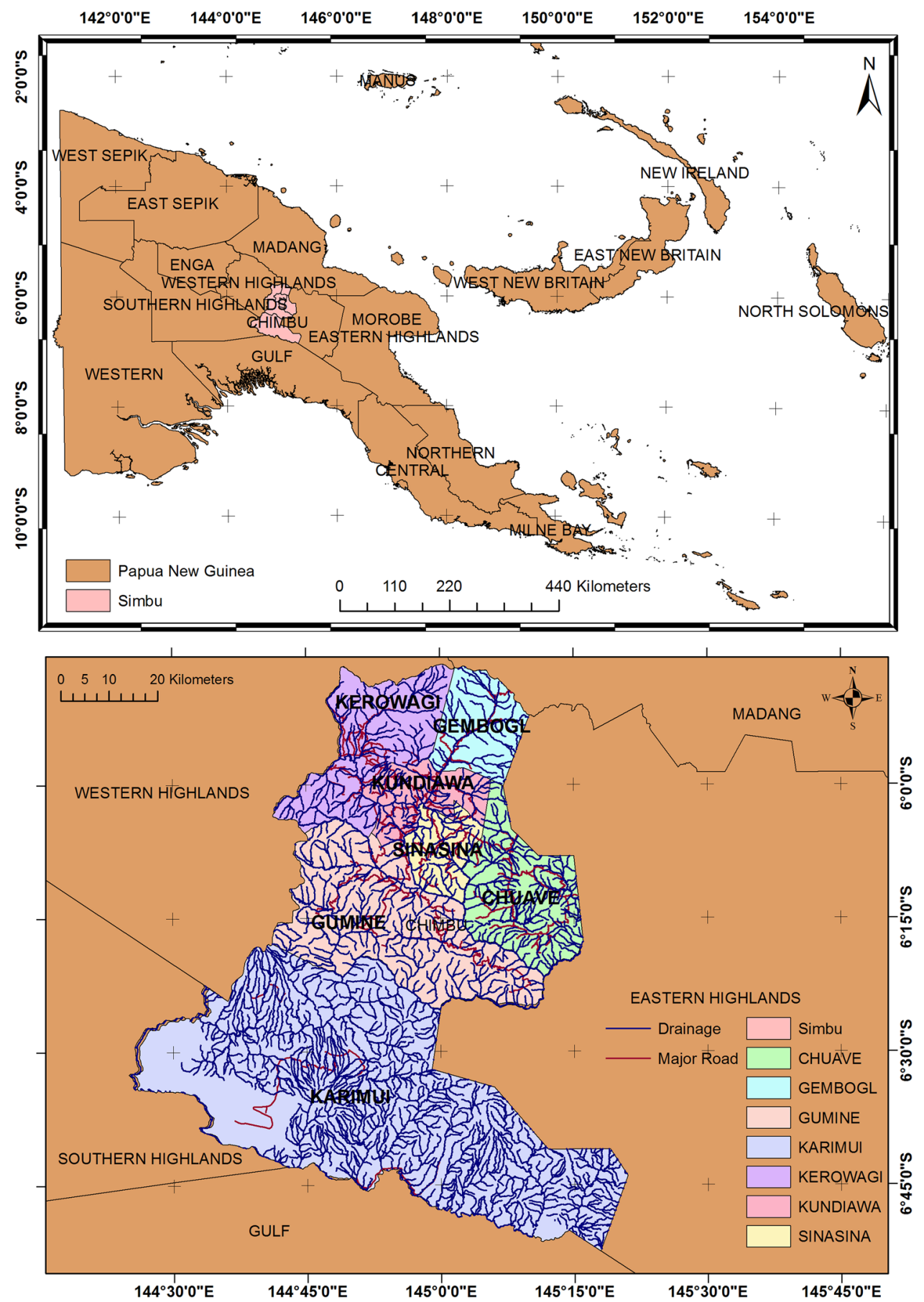
rainforest occurring below $1200 \mathrm{~m}$, two layer lower montane forest occurring between 1000 and $3000 \mathrm{~m}$ and above $3000 \mathrm{~m}$ is dominated by montane forest and occasional grassland propagating to bare land at summit areas (Bain and Mackenzie 1975). Grassland, secondary forest and gardens dominate areas below $2000 \mathrm{~m}$ due to population concentration along economic corridors and infrastructure developments.

The Simbu Provincelies within the highlands geomorphological region that forms part of the Central Cordillera that includes the Southern Fold Mountains, the Northern and Eastern Metamorphic Ranges (Loffler 1977). This uninterrupted chain of mountains stretches from the southern tip of the country to West Iran in the west. The region is further divided into mountains and inter-montane valleys (Bain and Mackenzie 1974). According to Bain and Mackenzie (1974) drainage is controlled by structures and lithology. The main river systems draining the study area include; 1st Order tributaries, Magiro (Mairi), Chimbu and Koronigle, 2nd Order Wahgi River draining the middle region whilst 3rd Order Tua drains the southern Region.

Papua New Guinea is a very tectonically active country and forms part of the Pacific Ring of Fire. Collision between the north migrating Indo-Australian Plate and northwest-moving Pacific Plate have developed three main northwest-southeast trending geotectonic provinces; Fly platform, Central Cordilera and Island arc (Davies et al. 1997). The Fly Platform is part of the Indo-Australian Plate and is relatively flat-lying underformed sedimentary rocks. The Central Cordillera is sandwiched between the two major plates resulting in high elevation and structural complexity. It comprises of the New Guinea Mobile Belt and Papuan Fold Belt to the north and south respectively. Major folding and faulting affects the region resulting in high elevations (Ripper and Letz 1991). The study area is located within the Central Cordillera, home to the highest mountain on the country. The Island Arc, mainly volcanic in origin comprises of the New Guinea Islands and the accreted adelbert-Finisterre-Saruwaged Range in Madang and Morobe Provinces.

With massive area of approximately $6157 \mathrm{~km}^{2}$, major economical corridor only makes up $9 \%$ of the area, comprising only approximately $556 \mathrm{~km}$ of road infrastructure concentrated in the upper northern part of the province. Except for Karimui district, all districts are connected to the provincial capital (Fig. 1). The Highlands Highway (Okuk), major economical corridor stretches approximately $58 \mathrm{~km}$ from Mangiro on the eastern boundary with the Eastern Highlands Province (EHP) and Munde, western boundary with the Jiwaka Province at latitude $145.14^{\circ} \mathrm{E}$, longitude $6.10^{\circ} \mathrm{S}$ and latitude $144.85^{\circ} \mathrm{E}$, longitude $5.94^{\circ} \mathrm{S}$ respectively. It traverses from east to west through Chuave, Sinasina, Kundiawa, Gembogl, and Kerowagi districts respectively (Fig. 1). Table 1 shows the distribution of road in each district.

\section{Landslide in Simbu Province}

The Simbu Province is known for landslide occurrences that has had significant repercussions on the economy of the country and detrimental effects on vulnerable communities. Most of this occurs predominately within the late cretaceous Chim Formation, a dark grey mudstone and siltstone with interbedded volcaniclastic sandstone (Blong 1981). Though competent when intact, the shale disintegrates faster during exposure (Peart 1991). Those investigated can be grouped into either earth characteristic of predominately fines soils and debris, predominately coarse soils (Varnes 1978). Table 2 shows some major landslides investigated along the $1 \mathrm{~km}$ corridor of the Highlands Highway.

The Gera Landslide located at longitude $145.03^{\circ} \mathrm{E}$ and latitude $6.05^{\circ} \mathrm{S}$. It is a complex rotational slump-debri flow that occurred during a period of continuous heavy rainfall and affected an area of $\sim 53$ hectares. The scarp is $\sim 300 \mathrm{~km}$ from the base of the in situ limestone trending northwest southeast. It displaced 2000 people and cover $500 \mathrm{~m}$ of the Highlands Highway.

\section{Materials used for the study}

Papua New Guinea (PNG) like many developing countries is venturing into new technologies and techniques to manage its resources and associated risk including landslide occurrences in the recent past. It is slowing moving away from the traditional field orientated method and incorporating the application of remote sensing and GIS to assist planning and management processes. Remote sensing is acquiring information of areas or objects of interest from instruments not in contact with the target (Lillesand et al. 2007). This information is fed into a GIS environment for manipulation, analysis and extraction of information.

It was a challenge to make greater use of the available data sets and quantitatively assess its application for the intended purpose. Landsat 8 images with cell size $30 \mathrm{~m} \times 30 \mathrm{~m}$ resolution were collected from the Department of Surveying, PNG University of technology and reprojected to UTM projection system, Zone 55S using Erdas Imagine. Using Data Preparation tools, the scenes were moisacked and with a defined area of interest (AOI), the study area was clipped out to compress the image volume using the Simbu Provincial Boundary. Table 3 shows details of the images used. Image enhancement 
Table 1 Road coverage in the Simbu Province, PNG

\begin{tabular}{llcccc}
\hline No & District & Land area $\left(\mathrm{km}^{2}\right)$ & $\begin{array}{l}\text { Road length } \\
(\mathrm{km})\end{array}$ & $\begin{array}{l}\text { District road } \\
\text { coverage }(\%)\end{array}$ & $\begin{array}{l}\text { Provincial road } \\
\text { coverage }(\%)\end{array}$ \\
\hline 1 & Chuave & 571.2 & 137.2 & 24.02 & 2.23 \\
2 & Sinesine/Yogumugl & 325.2 & 101.7 & 31.27 & 1.65 \\
3 & Kundiawa/Gembogl & 440.4 & 80.36 & 18.25 & 1.31 \\
4 & Kerowagi & 610.6 & 100.3 & 16.43 & 1.63 \\
5 & Gumine & 701.8 & 78.46 & 11.18 & 1.27 \\
6 & Karimui & 3508 & 58.02 & 1.65 & 0.94 \\
7 & Simbu Section (HHW) & & 57.5 & & 9.03 \\
8 & Total & 6157.2 & 556.04 & 9.03 \\
\hline
\end{tabular}

Table 2 Recent major landslides in Simbu Province and vicinity

\begin{tabular}{|c|c|c|c|}
\hline Location & Date & Mechanism & Description \\
\hline Mount Wilhelm, Simbu province & 16 Feb 2016 & Massive files of debris & $\begin{array}{l}\text { Heavy rain triggered, } 27,000 \text { people affected, } 11 \\
\text { schools were closed }\end{array}$ \\
\hline $\begin{array}{l}\text { Kenagi Landslide, Eastern } \\
\text { Highlands Province }\end{array}$ & 4 Nov 2013 & Debris slide-mudflow & $\begin{array}{l}\text { Rainfall triggered, Rapid movement, } 11 \text { fatalities, } \\
\text { HHW closed for } 2 \text { weeks }\end{array}$ \\
\hline $\begin{array}{l}\text { Waingarr Landslide, Kerowagi } \\
\text { District }\end{array}$ & 3 Mar 2013 & Rotational slide & $\begin{array}{l}\text { Occurred immediately after rainfall, displaced } 1000 \\
\text { people, HHW closed for } 3 \text { weeks }\end{array}$ \\
\hline Porok Landslide, Sinasina District & 23 Feb 2012 & Debris slide & $\begin{array}{l}\text { Occurred immediately after rainfall, displaced } 500 \\
\text { people, massive destructions of coffee and food } \\
\text { gardens }\end{array}$ \\
\hline $\begin{array}{l}\text { Lurape Landslide, Watabung, } \\
\text { Eastern Highlands Province }\end{array}$ & 13 Mar 2009 & Debris slide & $\begin{array}{l}\text { Rapid, occurred during heavy rainfall, } 14 \text { fatalities, } \\
\text { HHW closed for } 2 \text { weeks }\end{array}$ \\
\hline Gera Landslide, Simbu Province & 08 Apr 2008 & $\begin{array}{l}\text { Rotational slump/debris } \\
\text { flow }\end{array}$ & $\begin{array}{l}\text { Displaced over } 2000 \text { people, occurred during weeks } \\
\text { of heavy rainfall, reactivation of old landslide }\end{array}$ \\
\hline $\begin{array}{l}\text { Kerowagi Police Station, Simbu } \\
\text { Province }\end{array}$ & August 1979 & Rotational slump & $\begin{array}{l}\text { Slow movement in unconsolidated soils, occurred } \\
\text { during heavy rainfall. (Greenbaum et al. 1995) }\end{array}$ \\
\hline $\begin{array}{l}\text { WaraTamba Landslide, Simbu } \\
\text { Province }\end{array}$ & October 1970 & $\begin{array}{l}\text { Mudslide initial soil } \\
\text { creep-current }\end{array}$ & $\begin{array}{l}\text { Currently very active creep movement. Occurred } \\
\text { after heavy rainfall and earthquake. Occurred } \\
\text { within weathered Chim Formation. (Greenbaum } \\
\text { et al. 1995) }\end{array}$ \\
\hline
\end{tabular}

technique was carried out to easy identification of feature during classification.

Almost all recorded individual landslides in the province occurred during or immediately after continuous heavy or continued periods of intermittent rainfall normally during the northwest monsoon period from October to April but to locate this is greatly hindered by cloud cover. Furthermore, re-growth of vegetation and/or vegetation cover within the slip area hinders recognition of landslide features. Land use/land cover classification was done using the supervised classification tool in Erdas Imagine here then the Normalised Differential Vegetation Index (NDVI) spectral enhancement technique due to high cloud cover. NDVI index is a measure of the greenness or health stage of the vegetation cover. As shown on Table 3, collateral datasets were collated from various sources depending on the parameters identified as having a degree of influence on landslides occurrence in the Simbu Province.

\section{Detailed methodology}

WLC method is extensively used for landslide susceptibility and hazard mapping due to its application flexibility and expertise knowledge depended. WLC is commonly used amongst researchers and landslide specialist but lacks clear refining steps to derive higher degree of accuracy probability maps (Malczewski 2000). WLC is based on combining weighted averages of a number of parameters selected by the expert. There are no set criteria but purely on expert knowledge. The outcome can significantly vary between experts. Each parameter is classed and multiplied with its assigned weight and within a GIS overlay environment; the weighted averages are added to get the final output map. For any study objective, highest summation scores are selected for suitability or susceptibility assessments.

The critical elements that define the accuracy of WLC method; 
Table 3 Satellite data and other collateral data layers used for the study

\begin{tabular}{lll}
\hline Data & Description & Source \\
\hline Landsat 8 Operational Land Imager & Path/Row & Unitech-Surveying and Land Study \\
& $97 / 64-14$ November 2013 & \\
& $97 / 65-22$ March 2014 & \\
& $98 / 64-17$ June 2014 & \\
Slope angle & Derived from DEM $90 \mathrm{~m}$ (SRTM) & \\
Elevation (m) & Derived from DEM 90 m (SRTM) & \\
Aspect & Derived from DEM 90 m (SRTM) & Forestry Department \\
Vegetation cover & Extracted and generated & PNG Geological map: 1:250 000 \\
Lineaments & Clipped from PNG geological map using Simbu Boundary & The Papua New Guinea Resource \\
Rainfall data & Extracted and generated & Information System (PNGRIS-2009) \\
Soil texture & Extracted and generated & \\
Landform & Extracted and generated & The University of Papua New Guinea \\
Lithology & Extracted and reclassed & Remote Sensing Centre \\
Roads & Extracted & (Provincial Geobook-2009) \\
Rivers & Extracted & Field data/internet study and other research \\
District boundary & Extracted &
\end{tabular}

1. How weights are assigned to each parameter (expert knowledge, experience)

2. Selection of GIS procedures to derive the final output (maps)

In WLC, the weight of each parameter considered is added by means of overlay as in the Eq. 1 .

$S=W_{i} X_{i}$

where $\mathrm{S}$ is the susceptibility, $\mathrm{W}_{\mathrm{i}}$ denotes weight of factor and $\mathrm{X}_{\mathrm{i}}$ is the criterion score of factor. The different factors are combined by adding their weight to obtain the final output. Multi-criteria-weighted linear combination method was used in this study. The flow chart below shows the methodology used to generate landslide susceptibility map using 10 parameters (Fig. 2).

\section{Slope of the area}

Slopes are dynamic systems enabling movement of material downslope at varying speeds from negligibly slow to fast avalanche. Slope can be divided according to processes; convex slope or crest, nearly vertical free-face (cliff), debris slope at $\sim 30^{\circ}-45^{\circ}$ and wash slope. Near vertical free-face are associated with resistant rocks whilst wash slope indicates depositional characteristics, angles less than convex slope. Debris slope or repose angle is the maximum slope at which loose material can still be maintained (Ladas et al. 2007). Slope higher than repose angle increases shear stress of unconsolidated material.
Slope gradient also acts as a controlling agent for subsurface water distribution, surface runoff rate and soil water content during or after rainfall. Low and near vertical slope angles are less susceptible to landslides. Slope gradient between $30^{\circ}$ and $45^{\circ}$ are prone to mass movement. Slope was generated from cell size $90 \mathrm{~m} \times 90 \mathrm{~m}$ DEM (SRTM) using ArcGIS spatial analysis tool. The slope range from 0 to $73^{\circ}$, higher angles indicative of abrupt limestone escarpments. The slope map was reclassed into 5 categories: less than $10^{\circ}, 10-20^{\circ}, 20-30^{\circ}, 30-40^{\circ}$ and more than $40^{\circ}$ (Fig. 3a).

\section{Elevation}

Elevation was extracted and generated from the $90 \mathrm{~m} \times 90 \mathrm{~m}$ cell size DEM ranging from 0 to $4450 \mathrm{~m}$. Using ArcGIS, spatial analyst tool, 6 classes were generated manually as <1000, 1000-1500, 1500-2000, 2000-2500, 200-2500, 2500-3000 and >3000 m (Fig. 3b).

\section{Rainfall}

Incidences of approximately $80 \%$ of landslide occurrence investigated in PNG, especially in the Simbu Province have either occurred during the rainy season or immediately after a prolonged or intermitted heavy rainfall. Rainfall behaves as a triggering agent for a landslide event given conducive causative parameters. The annual rainfall for the Simbu Province increases southwards from $2000 \mathrm{~m}$ in the 


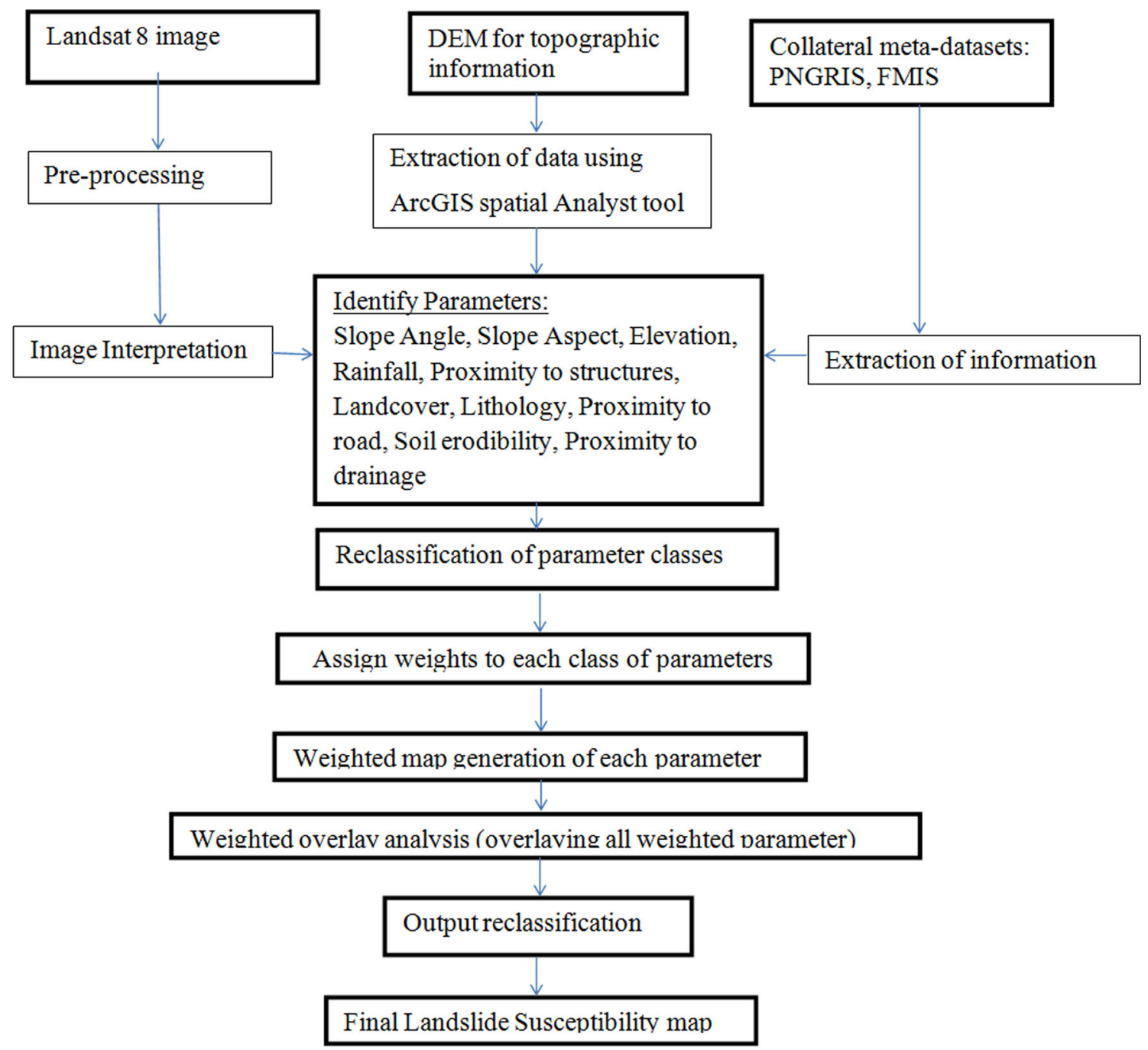

Fig. 2 Methodological flow chart of study

central to $5000 \mathrm{~m}$ in the south (Bain and Mackenzie 1975). The annual rainfall data retrieved from PNGRIS metadata ranges from 1700 to $4600 \mathrm{~mm}$ within the study area and reclassed into 5 categories, $<2000,2000-2500,2500$ $3000,3000-3500$ and $>3500 \mathrm{~mm}$ (Fig. 3c).

\section{Vegetation cover}

Vegetation cover plays an important role in reducing soil erosion. Extensive network of root system provide natural interlocking anchorage of the soil layer along slopes. Highly vegetated slope area generally reduces the effects of soil erosion along the slopes which reduces the susceptibility of landslides and mass movements. Comparatively, a barren area with less or no vegetation is highly prone to erosional activities. Vegetation class was extracted from Forest Information Management System (FIMS). Six vegetation classes were extracted and reclassed into 5 classed; Low attitude forest, Grassland, Lower montane forest, Montane Forest and Urban or built-up areas (Table 4; Fig. 3d).

\section{Proximity to lineament}

Geological structures such as faults, folds, joints, bedding and shear zones have a greater influence on the stability of the slopes. That inter-relationship can be exacerbated by rainfall or earthquake causing failure along these zones of weakness (Kanungo et al. 2009). The proximity of a slope to these features greatly influences its stability, increasing the susceptibility of landslides occurrence. Major folding and faulting affects the region as two opposing plates, Australian Plate and Pacific Plates moving in a NNE and WSW direction respectively (Ripper and Letz 1991) resulting in the structural complexity and higher elevation. Mt Wilhelm is evident of the orogenic events. The 
Fig. 3 Slope (a), elevation (b), rainfall (c) and vegetation (d) characteristics of Simbu

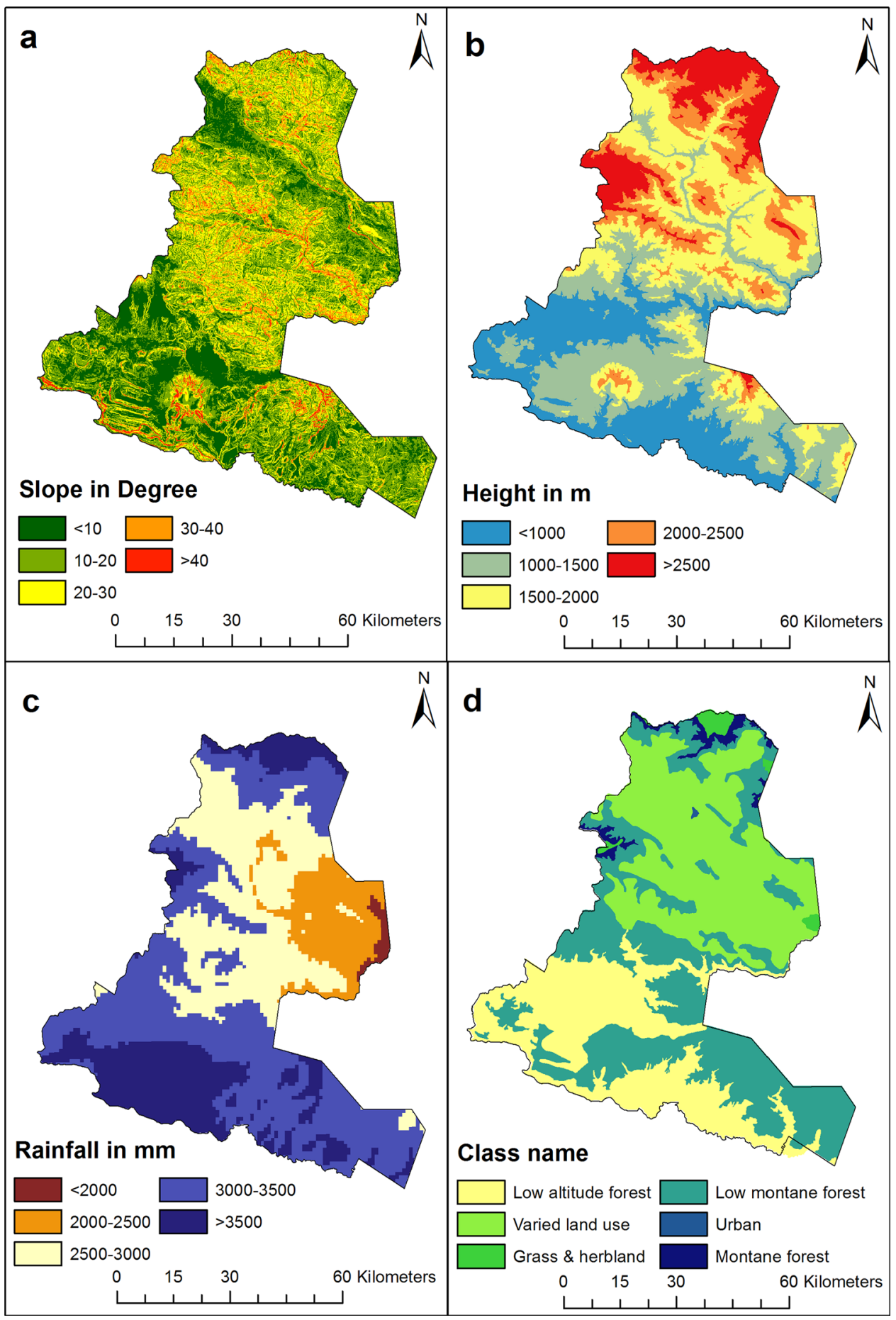

lineaments were cropped out from PNG Geological Map, 1:250,000 scale using the Simbu Provincial Boundary layer in MapInfo version 10, cookie cutter tool. Using the universal translator, the layer was converted to shape file format for ArcGIS. Proximity buffer of 50, 100, 150, 200 and $250 \mathrm{~m}$ were generated using ArcGIS analysis tool. The shape file was again converted to raster file using the conversion tool in ArcGIS (Fig. 4a). The risk decreases with increasing distance from the structure.

Proximity to road

Proximity to road is considered because of the terrain of the study area. The road is cut through approximately 
Table 4 Vegetation classes found in Simbu Province, PNG

\begin{tabular}{llll}
\hline $\begin{array}{l}\text { Old } \\
\text { value }\end{array}$ & Veg class & $\begin{array}{l}\text { New } \\
\text { value }\end{array}$ & Rank \\
\hline 2 & Low altitude forest on uphill, below 1000 m & 1 & 1 \\
5 & Land use intensity class 1-4 & 2 & 5 \\
7 & Grass \& shrub land & 3 & 4 \\
11 & Lower montane forest, above 1000 m & 4 & 2 \\
13 & Urban & 2 & 5 \\
14 & Montane forest & 5 & 3 \\
\hline
\end{tabular}

$556 \mathrm{~km}$ of mountainous terrain including $\sim 58 \mathrm{~km}$ of the Highlands Highway. Road cuts at the outset decrease the general stability of the slopes and increase depending on the dip directions lithological units. Effects of induced vibration from moving trucks or vehicles are also considered based on hypotheses that rebound settling time is not sufficient before another truck passes over. This artificial vibrations and surcharge along slope cuts can induce or increase instabilities (Pourghasemi et al. 2012).Numerous subsidence and encroachment along the
Fig. 4 Proximity distance to lineament (a), road (b) and drainage (c) of the study area

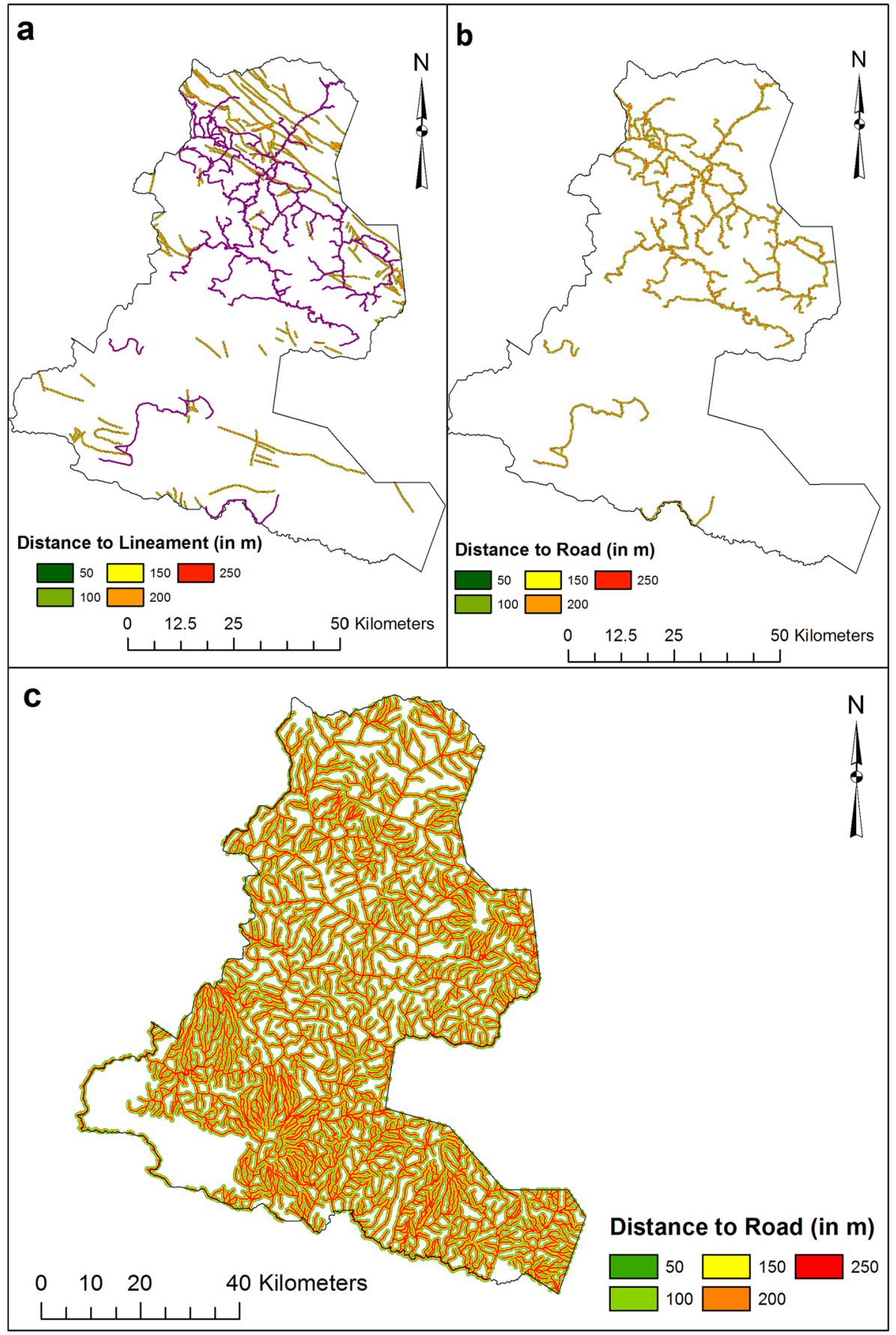


Table 5 Landuse/Landcover classified from Landsat 8 image

\begin{tabular}{llll}
\hline Class & Old value & New value & Rank \\
\hline Water & 1 & 1 & 1 \\
Forest land & 2 & 2 & 2 \\
Shrub land & 3 & 3 & 3 \\
Barren land & 4 & 5 & 5 \\
Agricultural land & 5 & 4 & 4 \\
Built-up & 6 & 5 & 5 \\
\hline
\end{tabular}

HHW Section is indicative of induced slope instabilities. Notable active soil creep encroachments are found between Chuave and Gera Areas and between Wandi and Mindima, Tinenigle and Wainngar along the Highlands Highway.

Risk decreases as distance increases away from the road corridor. Multiple ring buffers of 50, 100, 150, 200 and $250 \mathrm{~m}$ were generated using ArcGIS analyst tool. PNG standard road corridor $40 \mathrm{~m}$, demarcation includes $8 \mathrm{~m}$ of
Fig. 5 Land use land cover (a), landform type (b) and geological (c) characteristics of the study area

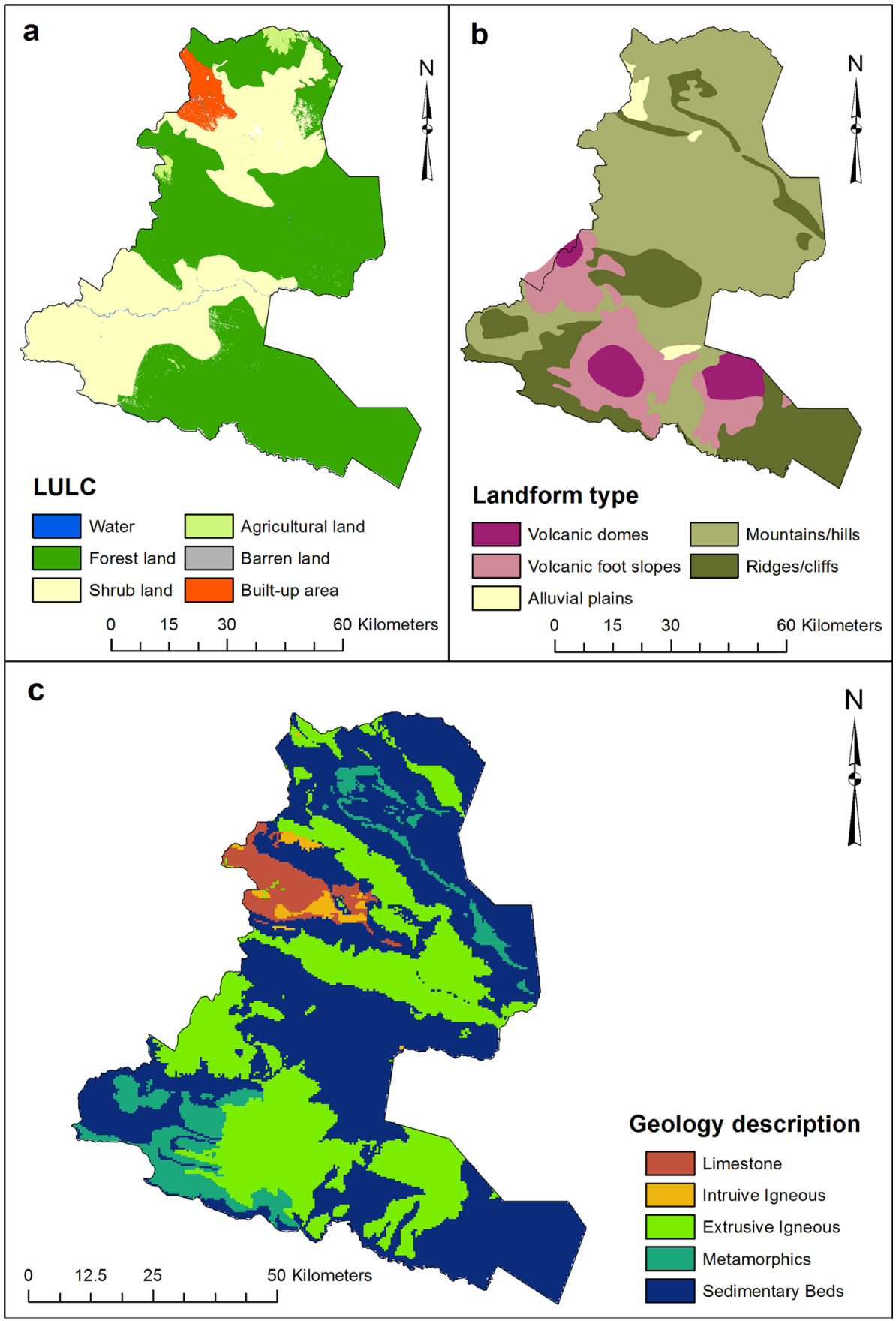


Table 6 General landform types found in Simbu Province, PNG

\begin{tabular}{llll}
\hline Code & Landform type & Class & Ranks \\
\hline 13 & $\begin{array}{l}\text { Composite alluvial plains } \\
30\end{array}$ & 1 & 3 \\
$\quad \begin{array}{l}\text { Little dissected or undissected relict alluvial, } \\
\text { colluvial mudflow or fans }\end{array}$ & 1 & 3 \\
31 & $\begin{array}{c}\text { Dissected relict alluvial, colluvial mudflow } \\
\text { and fans }\end{array}$ & 1 & 3 \\
32 & $\begin{array}{l}\text { Little dissected volcanic footslopes and } \\
\text { volcano-alluvial fans }\end{array}$ & 2 & 2 \\
$50 \quad \begin{array}{l}\text { Hilly terrain with weak or no structural } \\
\text { control }\end{array}$ & 3 & 4 \\
51 & $\begin{array}{l}\text { Mountains and hills with weak or no } \\
\text { structural control }\end{array}$ & 3 & 4 \\
53 & $\begin{array}{l}\text { Homoclinal ridges and cuestas: inclined } \\
\text { asymmetrical structurally controlled ridges }\end{array}$ & 4 & 5 \\
54 & $\begin{array}{l}\text { Strike ridges and hogback ridges: steep, sharp } \\
\text { crested structurally controlled ridges }\end{array}$ & 4 & 5 \\
56 & \begin{tabular}{l} 
Volcanic cones and domes \\
\hline
\end{tabular} & 5 & 1 \\
\hline
\end{tabular}

actual sealed road and $16 \mathrm{~m}$ of road reversed boundary (Fig. 4b).

\section{Proximity to drainage}

River channels are both erosional and depositional agents depending on the energy and flow rate. Some of the world's high energy river systems are found in high altitude regions and are prime source of erosion and transportation agents. Undercutting by rivers reduce slope stability thus increasing the susceptibility of landslides and mass movement. This increases in areas of high drainage density and higher altitude. Using the ArcGIS analyst tool, multi-ring buffer was generated at 50,100,150,200 and $250 \mathrm{~m}$. The risk decreases away from the river channel (Fig. 4c).

\section{Land use/land cover}

Change in land cover and land cover time greatly influences the slope stability and erosional activities. Land use change is depended on the population and their needs for survival that include deforestation, conversion of forest for agricultural purposes and unplanned or unprofessional slope cutting for infrastructure developments. The Simbu Province is dominated by dense forest, montane forest and low montane forest with scattered barren land found above $3000 \mathrm{~m}$ (Bain and Mackenzie 1975). Agricultural areas and grassland found in areas of high population density especially along economic corridors and low lands. For the purpose and scale of this study, the general types of LULC were identified by using the raster brightness/contrast tool
Table 7 Classed table with assigned ranks and weights

\begin{tabular}{|c|c|c|c|c|}
\hline Parameters & Class & Rank & Weight & Comments \\
\hline $\begin{array}{l}\text { Slope angle } \\
\text { (in degree) }\end{array}$ & $\begin{array}{l}<10 \\
10-20 \\
20-30 \\
30-40 \\
>40\end{array}$ & $\begin{array}{l}1 \\
2 \\
3 \\
4 \\
5\end{array}$ & 4 & $\begin{array}{l}\text { The study area is very } \\
\text { rugged The region is } \\
\text { highly rugged and } \\
\text { mountainous. Slope } \\
\text { angles can } \\
\text { sometimes be } \\
\text { almost } 90^{\circ} \text { at } \\
\text { limestone cliff faces }\end{array}$ \\
\hline $\begin{array}{l}\text { Elevation (in } \\
\mathrm{m} \text { ) }\end{array}$ & $\begin{array}{l}<1000 \\
1000-1500 \\
1500-2000 \\
2000-2500 \\
>2500\end{array}$ & $\begin{array}{l}1 \\
2 \\
3 \\
4 \\
5\end{array}$ & 1 & $\begin{array}{l}\text { The elevation ranges } \\
\text { from } 164 \text { to } 4450 \mathrm{~m}\end{array}$ \\
\hline $\begin{array}{l}\text { Rainfall (in } \\
\mathrm{mm} \text { ) }\end{array}$ & $\begin{array}{l}<2000 \\
2000-2500 \\
2500-3000 \\
3000-3500 \\
>3500\end{array}$ & $\begin{array}{l}1 \\
2 \\
3 \\
4 \\
5\end{array}$ & 2 & $\begin{array}{l}\text { Individually } \\
\text { investigated } \\
\text { landslides in the } \\
\text { study area occurred } \\
\text { during or } \\
\text { immediately after } \\
\text { the heavy or } \\
\text { continuous rainfall }\end{array}$ \\
\hline $\begin{array}{l}\text { Proximity to } \\
\text { lineaments } \\
\text { (in } \mathrm{m} \text { ) }\end{array}$ & $\begin{array}{l}50 \\
100 \\
150 \\
200 \\
250\end{array}$ & $\begin{array}{l}5 \\
4 \\
3 \\
2 \\
1\end{array}$ & 1 & $\begin{array}{l}\text { The presence of } \\
\text { lineaments is } \\
\text { indicative of a weak } \\
\text { area that is } \\
\text { susceptible to } \\
\text { landslide }\end{array}$ \\
\hline $\begin{array}{l}\text { Land use } \\
\text { land cover }\end{array}$ & $\begin{array}{l}\text { Forest land } \\
\text { Shrub land } \\
\text { Agriculture } \\
\text { land } \\
\text { Barren land } \\
\text { Built-up area } \\
\text { Water }\end{array}$ & $\begin{array}{l}2 \\
3 \\
4\end{array}$ & 1 & $\begin{array}{l}\text { Sparsely populated in } \\
\text { remote areas. High } \\
\text { population } \\
\text { concentrated along } \\
\text { road corridors }\end{array}$ \\
\hline $\begin{array}{l}\text { Geological } \\
\text { unit }\end{array}$ & $\begin{array}{l}\text { Sedimentary } \\
\text { beds } \\
\text { Limestone } \\
\text { Extrusive } \\
\text { igneous } \\
\text { Intrusive } \\
\text { igneous } \\
\text { Metamorphics }\end{array}$ & $\begin{array}{l}4 \\
3\end{array}$ & 1 & $\begin{array}{l}\text { Landslide occurrence } \\
\text { in the Highlands } \\
\text { region are } \\
\text { associated with the } \\
\text { Chim Formation }\end{array}$ \\
\hline $\begin{array}{l}\text { Proximity to } \\
\text { road (in m) }\end{array}$ & $\begin{array}{l}50 \\
100 \\
150 \\
200 \\
250\end{array}$ & $\begin{array}{l}5 \\
4 \\
3 \\
2 \\
1\end{array}$ & 1 & $\begin{array}{l}\text { Road cutting in high } \\
\text { elevation and slope } \\
\text { angle significantly } \\
\text { decreases the } \\
\text { stability of the } \\
\text { formation }\end{array}$ \\
\hline $\begin{array}{l}\text { Vegetation } \\
\text { cover }\end{array}$ & $\begin{array}{l}\text { Montane } \\
\text { forest } \\
\text { Low montane } \\
\text { forest } \\
\text { Low attitude } \\
\text { forest } \\
\text { Grassland } \\
\text { Urban/built- } \\
\text { up areas }\end{array}$ & $\begin{array}{l}4 \\
5\end{array}$ & 1 & $\begin{array}{l}\text { High vegetation cover } \\
\text { has roots that act as } \\
\text { anchorage for soil } \\
\text { hence erosional } \\
\text { processes }\end{array}$ \\
\hline
\end{tabular}


Table 7 continued

\begin{tabular}{|c|c|c|c|c|}
\hline Parameters & Class & Rank & Weight & Comments \\
\hline \multirow{5}{*}{$\begin{array}{l}\text { Proximity to } \\
\text { drainage } \\
\text { (in m) }\end{array}$} & 50 & 5 & \multirow[t]{5}{*}{1} & \multirow{5}{*}{$\begin{array}{l}\text { River channels can } \\
\text { behave as erosional } \\
\text { or depositional } \\
\text { agents. } \\
\text { Undercutting of } \\
\text { river increases the } \\
\text { probability of } \\
\text { landslide }\end{array}$} \\
\hline & 100 & 4 & & \\
\hline & 150 & 3 & & \\
\hline & 200 & 2 & & \\
\hline & 250 & 1 & & \\
\hline \multirow[t]{5}{*}{ Landform } & $\begin{array}{c}\text { Alluvial } \\
\text { plains }\end{array}$ & 3 & \multirow[t]{5}{*}{1} & \multirow{5}{*}{$\begin{array}{l}\text { Mountains and hill is } \\
\text { the dominate } \\
\text { landform of high } \\
\text { landslide } \\
\text { vulnerability }\end{array}$} \\
\hline & $\begin{array}{l}\text { Volcanic foot } \\
\text { slopes }\end{array}$ & 2 & & \\
\hline & $\begin{array}{r}\text { Mountains } \\
\text { and hills }\end{array}$ & 4 & & \\
\hline & $\begin{array}{l}\text { Ridges and } \\
\text { cliffs }\end{array}$ & 5 & & \\
\hline & $\begin{array}{c}\text { Volcanic } \\
\text { domes }\end{array}$ & 1 & & \\
\hline
\end{tabular}

and supervised classification in Erdas Imagine version 8 using Landsat images. (Table 5). LULC classes identified are Water, Forest land, Shrub land, Barren land, Agricultural land and built-up land and merged further into 5 classes (Fig. 5a).

\section{Landforms}

Landforms are characteristic of dominant geomorphological processes by which they are formed and can be categorised as depositional, erosional or volcanic landforms. Some can be extensive and have recurring patterns which can have fairly uniform land use potential. The different land use application influence erosional activity at different scale. According to PNGRIS metadata, Simbu Province has characteristics of the three landforms. The landforms were categorized into five classes: Alluvial plains (1), Volcanic foot slopes (2), mountains and hills (3), Ridges and cliffs (4) and volcanic domes (5). Table 8 shows the description of landforms found in the Simbu Province with merging done to regroup into five rank (Table 6; Fig. 5b).

\section{Geology}

Geological data was extracted from PNGRIS metadata. The main rocks types found the Simbu Province was have been classed into sedimentary limestone, sedimentary beds, intrusive igneous, extrusive igneous and metamorphic. These units can be stable but depending on their exposure to weathering or proximity to structures can become vulnerable to landslides. Comparatively, limestone is ranked 1 and sedimentary beds at 5 . Different lithological units behave differently depending on their composition, texture, degree of weathering in relation of slope stability (Kanungo et al.
2009). These internal characteristics can influence the permeability and shear strength of the parent rock (Fig. 5c).

The general causative parameters and mechanisms of landslide are understood but their degree of influence varies significantly between geographical locations (Greenbaum et al. 1995). Depending on expert knowledge and scale of study, certain parameters are selected as inputs. Numerous individually investigated and recorded landslide occurrences in the Simbu Province are related to rainfall triggered failures and occurring predominately within the Late Cretaceous Chim Formation, a gray-black, micaceous, finely laminated mudstone and siltstone, interbedded with sandstone, shale, conglomerate, calcarenite and limestone. Ten parameters have been selected for this study; Slope angle, elevation, rainfall, proximity to lineaments, vegetation cover, land use/land cover, geological unit, proximity to road, proximity to drainage, and landform. Each parameter was classed and comparative ranking were assigned. These were further assigned a weight according to their degree of influence with relevance with the other parameters. Table 7 , shows the values assigned to the various parameters. The ranks range from 5-very high, 4- high, 3-moderate, 2-low and 1-very low. The total weight for the selected parameters is 14 , with weight ranging from a low 1 to 4 , high.

The weighted linear combination (WLC) method, involving multiple parameters is used to establish the relational importance and degree of influence of the selected parameters to enable a landslide event in a GIS environment (Mahini and Gholamalifard 2006; Ladas et al. 2007). According to Ladas et al. 2007, there is no standard number of parameters or type of parameter to be selected which gives a degree of difficulty for WLC method users, it depends on expert and local knowledge.

Each parameter was categorized into classes and assigned ranks from having very low influence to very high, 1 (very low) - 5 (very high) depending on the classes bearing on landslides. With a weight total of 14 , divided between the 10 parameters, each is assigned a weight against other parameters. The classes within each parameter are multiplied with the weight and added using the spatial analysis tool to get susceptibility output maps. Following weighted linear combination (WLC) Model was used to generate landslide vulnerable maps. Landslide Vulnerability Mapping (LVM) was performed using following Eq. 2.

$$
\begin{aligned}
L V M= & (\text { Slope } \times 4)+(\text { rainfall } \times 2)+(\text { elevation }) \\
& +(\text { vegetation })+(\text { landform }) \\
& +(\text { geological unit })+(\text { proximityto road }) \\
& +(\text { proximity to lineaments }) \\
& +(\text { proximity to rivers })+(\text { Land Use Land Cover })
\end{aligned}
$$


Fig. 6 Landslide vulnerability map of Simbu Province, Papua New Guinea
Table 8 Provincial landslide risk zones in areas $\left(\mathrm{km}^{2}\right)$ and area $(\%)$

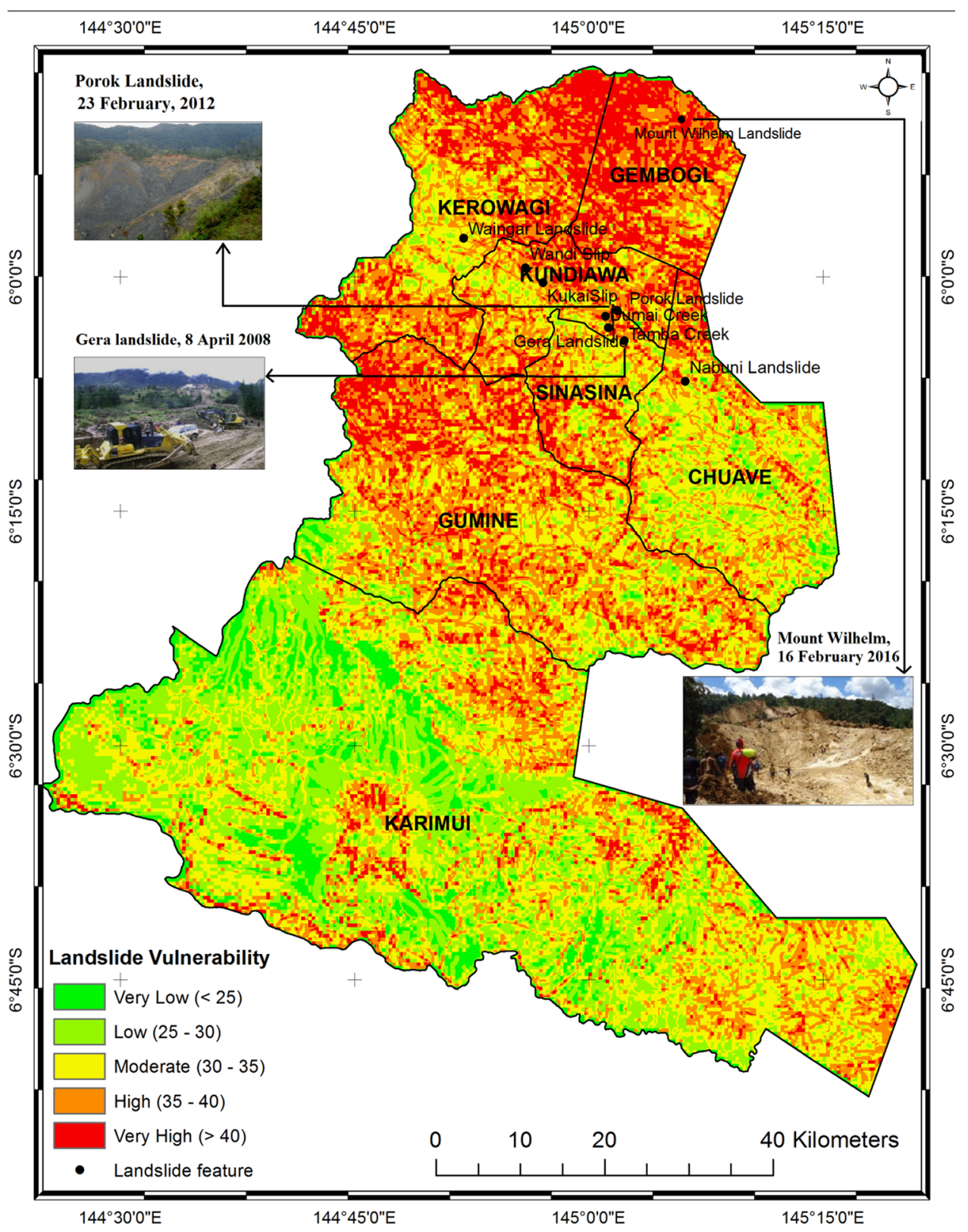

\begin{tabular}{lrrr}
\hline Risk index & Histogram & Area $(\mathrm{sq} \mathrm{km})$ & Area in $\%$ \\
\hline Very low & 4858633 & 393.55 & 6.21 \\
Low & $15,843,875$ & 1283.35 & 20.24 \\
Moderate & $25,261,788$ & 2046.20 & 32.27 \\
High & $21,040,944$ & 1704.32 & 26.88 \\
Very high & $11,280,909$ & 913.75 & 14.41 \\
\hline
\end{tabular}

\section{Results and discussion}

By following the methodological flow chart (Fig. 2), remote sensing data and collateral data was manipulated in the GIS environment. Each parameters identified to have influence on landslide occurrence in the Simbu Province were assessed, classed and ranked individually. Parameters used are slope, elevation, rainfall, vegetation cover, landform, geological unit, Land use/land cover, proximity to road, proximity to rivers and proximity to 
lineaments. Depending on their degree of influence to landslide comparatively to another parameter, weight were assigned and using GIS overlay capability, weighted sum was done to combine all parameters. Figure 6 shows the output of combining different weighted parameter using the WLC method within the ArcGIS weighted sum environment.

The ranks were assigned from very low to very high with the numerical value of 1-5 respectively. Figure 6 shows the distribution of the five susceptibility classes of the study area. Areas with very high landslide vulnerability zones are found in the northern and western parts of Simbu Province. Comparatively, southern parts have very low vulnerability areas. From the calculations done, $6.21 \%$ of area is at very low risk, $20.24 \%$ at low risk, $32.27 \%$ of moderate risk, $26.88 \%$ of high risk and $14.41 \%$ of very high risk area coverage. Table 8 shows the area $\left(\mathrm{km}^{2}\right)$ and percentage (\%) distribution of the 5 vulnerability classes generated. As shown in Table 8, the landslide susceptibility areas in percentage indicates a normal distribution curve. The moderate risk index has higher percentage and lower percentage at the two extremes, very low and very high.

Further extraction of pixel count at the district level was done to establish the districts at higher risk to landslides. Calculations done at the district level show that Kundiawa/ Gembogl district is highly susceptibility to landslides at $73.16 \%$, followed by Kerowagi District at $32.78 \%$, Gumine District at $20.47 \%$, Sinasina/Yougumugl at $17.06 \%$, Chuave District at $7.48 \%$. Karimui District has only $4.92 \%$ of very high risk zones (Table 9).

Tabulated data (Table 9) for the districts show some differences in the distribution of risk index. It gives an indication of the level of risk in each district. Kundiawa/ Gembogl districts risk index value trend is highly positively skewed. Kerowagi and Gumine are less skewed toward the higher vulnerable zones. Karimui district, larger district with a land mass of $3117.97 \mathrm{~km}^{2}$ has negatively skewed risk index trending. Sinasina and Chuave districts have normal distribution.

Finally a verification process was done with known landslide feature along the Highlands Highway Section including the major landslides in Gera, Porok and Waingar (Table 10). Most of the sites were either under very high vulnerability zone of high as the LVM model output (Fig. 6; Table 10).

\section{Conclusion and recommendations}

Landslides are a major geological hazard in any mountainous terrain with high slope angles and rainfall. Its effects can range from being negligible to detrimental depending on the mechanism and rate of movement.
Table 9 District level landslide risk zones of Simbu province

\begin{tabular}{|c|c|c|c|c|}
\hline District & Risk index & Histogram & Area (sq km) & Area in $\%$ \\
\hline \multirow[t]{6}{*}{ KEROWAGI } & Very low & 225,797 & 18.29 & 2.91 \\
\hline & Low & 279,287 & 22.62 & 3.60 \\
\hline & Moderate & $1,819,468$ & 147.38 & 23.44 \\
\hline & High & $2,893,508$ & 234.37 & 37.27 \\
\hline & Very high & $2,544,721$ & 206.12 & 32.78 \\
\hline & & & 628.79 & 100 \\
\hline \multirow[t]{6}{*}{ GEMBOGL } & Very low & 50,438 & 4.09 & 1.20 \\
\hline & Low & 41,388 & 3.35 & 0.98 \\
\hline & Moderate & 434,976 & 35.23 & 10.35 \\
\hline & High & $1,529,751$ & 123.91 & 36.40 \\
\hline & Very high & $2,145,921$ & 173.82 & 51.06 \\
\hline & & & 340.40 & 100 \\
\hline \multirow[t]{6}{*}{ KUNDIAWA } & Very low & 4883 & 0.40 & 0.14 \\
\hline & Low & 126,456 & 10.24 & 3.68 \\
\hline & Moderate & $1,087,714$ & 88.10 & 31.64 \\
\hline & High & $1,458,767$ & 118.16 & 42.44 \\
\hline & Very high & 759,650 & 61.53 & 22.10 \\
\hline & & & 278.44 & 100 \\
\hline \multirow[t]{6}{*}{ CHUAVE } & Very low & 240,660 & 19.49 & 3.24 \\
\hline & Low & $1,408,049$ & 114.05 & 18.96 \\
\hline & Moderate & $3,218,415$ & 260.69 & 43.33 \\
\hline & High & $2,004,383$ & 162.36 & 26.99 \\
\hline & Very high & 555,575 & 45.00 & 7.48 \\
\hline & & & 601.59 & 100 \\
\hline \multirow[t]{6}{*}{ SINASINA } & Very low & 8702 & 0.70 & 0.32 \\
\hline & Low & 230,104 & 18.64 & 8.48 \\
\hline & Moderate & 987,472 & 79.99 & 36.39 \\
\hline & High & $1,024,710$ & 83.00 & 37.76 \\
\hline & Very high & 462,866 & 37.49 & 17.06 \\
\hline & & & 219.82 & 100 \\
\hline \multirow[t]{6}{*}{ GUMINE } & Very low & 300,188 & 24.32 & 2.11 \\
\hline & Low & $1,112,056$ & 90.08 & 7.80 \\
\hline & Moderate & $4,324,336$ & 350.27 & 30.35 \\
\hline & High & $5,595,999$ & 453.28 & 39.27 \\
\hline & Very high & $2,916,489$ & 236.24 & 20.47 \\
\hline & & & 1154.17 & 100 \\
\hline \multirow[t]{6}{*}{ KARIMUI } & Very low & $4,027,965$ & 326.27 & 10.46 \\
\hline & Low & $12,646,535$ & 1024.37 & 32.85 \\
\hline & Moderate & $13,389,407$ & 1084.54 & 34.78 \\
\hline & High & $6,533,826$ & 529.24 & 16.97 \\
\hline & Very high & $1,895,687$ & 153.55 & 4.92 \\
\hline & & & 3117.97 & 100 \\
\hline
\end{tabular}

Landslide occurrences are inevitable but appropriate studies can assist in any planning purposes for infrastructure development and mitigation of its detrimental effects. The Simbu Province is highly susceptible to landslide occurrence especially the northern part of the province comprising Kerowagi and Kundiawa/Gembogl Districts. The 
Table 10 Landslide features along the Highlands Highway Sections of Simbu province

\begin{tabular}{lllll}
\hline ID & Feature_Name & Lat & Long & Landslide class \\
\hline 1 & Nabuni landslide & -6.1115 & 145.10313 & High \\
2 & Tamba Creek & -6.06787 & 145.03784 & High \\
3 & Dumai Creek & -6.04211 & 145.01768 & Very high \\
4 & Porok landslide & -6.03608 & 145.0304 & High \\
5 & Gera landslide & -6.05402 & 145.02091 & Very high \\
6 & Kukai slip & -6.00595 & 144.95117 & High \\
7 & Wandi slip & -5.99016 & 144.93232 & Very high \\
8 & Waingar landslide & -5.9585 & 144.86628 & Moderate \\
9 & Mount Wilhelm & -5.831 & 145.096 & Very high \\
\hline
\end{tabular}

region is highly rugged having slope angles greater than $30^{\circ}$, elevation above $2000 \mathrm{~m}$, high annual rainfall and intensive varied landuse practices. The northern part is structurally complex having a concentration of lineaments trending northwest southeast. The structurally complexity and proximity and proximal to roads increase the vulnerability to landslides. This region has higher density of lineaments, infrastructure development, high change in agricultural activities and population growth increasing the vulnerability of landslides. Remote Sensing and GIS tool are applicable in mapping landslide vulnerability in the highland region of Papua New Guinea. Number of contributing parameters and weight may differ between locations and experts. Following are recommendations made based on the study-(1) Effective disaster measures of awareness, preparedness and mitigation should be in-place to minimise the effects, (2) infrastructure development may be restricted or have stringent development polices of activities undertaken in higher risk zones and (3) set narrow classes of slope angles and rainfall at district levels to further assess the vulnerability at larger scale.

\section{Compliance with ethical standards}

Conflict of interest The authors declare that there is no conflict of interest for the publication of this article.

\section{References}

Bain JHC, Mackenzie DE (1974) Karimui, Papua New Guinea, Sheet SB/55-9. 1:250000 Geology Series, Explanatory Notes, Bureau of Mineral Resources Australia, and Geological Survey of Papua New Guinea

Bain JHC, Mackenzie DE (1975) Ramu, Papua New Guinea, Sheet SB/55-5. 1:250000 Geology Series, Explanatory Notes, Bureau of Mineral Resources, Australia, and Geological Survey of Papua New Guinea

Barredo JI, Hervas J, Lomoschitz A, Benavides A, Van WC (2000) Landslide hazard assessment using GIS and multi-criteria evaluation techniques in the Tirajana Basin, Gran Canaria Island (5th EC GIS Workshop)
Blong R J (1981) Stability analyses of Chim Shale mudslides, vol 132. IAHS AISH publication, Papua New Guinea. pp 42-66

Davies HL, Perembo RCB, Winn RD, KenGemar P (1997) Terranes of the New Guinea orogen. In: Hancock G (ed) Proceedings of the geology exploration and mining conference, madang: the australasian institute of mining and metallurgy, Melbourne, pp 61-66

Greenbaum D et al (1995) Rapid methods of landslide hazard mapping: Papua New Guinea case study: British Geological Survey Technical Report-WC/95/27

Kanungo DP, Arora MK, Sarkar S, Gupta RP (2009) Landslide susceptibility zonation (LSZ) mapping - a review. J South Asia Disaster Stud 2(1):81-105

Ladas I, Fountoulis I, Mariolakos I (2007) Using GIS and Multicriteria decision analysis in landslide susceptibility mapping-a case study in Messinia prefecture area (SW Peloponnesus, Greece). Bull Geol Soc Greece 40(4):1973-1985

Lillesand TM, Kiefer RW, Chipman JW (2007) Remote sensing and image interpretation, 6th edn, John Wiley \& Sons, New York, pp 1-772, ISBN: 978-0-4700-5245-7

Loffler E (1977) Geomorphology of Papua New Guinea. Australian National University Press, Canberra 195

Mahini AS, Gholamalifard M (2006) Siting landfills with a weighted linear combination methodology in a GIS environment. Int J Environ Sci Technol 3(4):435-445

Malczewski J (2000) On the use of weighted linear combination method in GIS: common and best practice approaches. Trans GIS 4(1):5-22

Nayak J (2010) Landslide risk assessment along a major road corridor based on historical landslide inventory and traffic analysis. International Institute for Geo-information Science and Earth Observation, Master Thesis, University of Twente, pp 1-109. https://www.itc.nl/

Nichol JE, Shaker A, Wong MS (2006) Application of high-resolution stereo satellite images to detailed landslide hazard assessment. Geomorphology 76:68-75

Peart M (1991) The Kalapit landslide: events and mechanisms. Q J Eng Geol 24:399-411

Pourghasemi H, Pradhan B, Gokceoglu C (2012) Application of fuzzy logic and analytical hierarchy process (AHP) to landslide suspectobiliyy mapping at Haraz watershed. Iran Nat Hazard 63:965-996

Ripper ID, Letz H (1991) Distribution and origin of large earthquakes in the Papua New Guinea region, 1900-1989. Papua New Guinea Geological Survey Report 91/5

Samanta S, Bhunia G (2013) Landslide susceptibility zone identification of Markham Watershed, PNG-a study based on remote sensing and GIS technology. Int J Phys Soc Sci 3(1):307-322

Samanta S, Pal DK, Lohar D, Pal B (2011) Preparation of digital data sets on land use/land cover, soil and digital elevation model for temperature modelling using Remote Sensing and GIS techniques. Indian J Sci Technol 4(6):636-642

Samanta S, Pal DK, Lohar D, Pal B (2012) Interpolation of climate variables and temperature modeling. Theor Appl Climatol Spinger 107(1):35-45. doi:10.1007/s00704-011-0455-3

Samy IE, Mohamed MM (2015) Mapping of tecto-lineaments and investigate their association with earthquakes in Egypt: a hybrid approach using remote sensing data. Geomat Natl Hazards Risk. doi:10.1080/19475705.2014.996612

Shahabi H, Hashim M (2015) Landslide susceptibility mapping using GIS-based statistical models and remote sensing data in tropical environment. Sci Rep 5:9899. doi:10.1038/srep09899

Varnes DJ (1978) Slope movement types and processes. In: Schuster RL, Krizek RJ (eds) Special Report 176: Landslides: Analysis and Control. Transportation and Road Research Board, National Academy of Science, Washington D. C., pp 11-33 